43. Notes on East African Snakes, collected 1918-1923.

By Arthur Loveridge, F.E.S., C.M.Z.S.

[Received August 14, 1023 : Read November 6, 1023.]

The 221 snakes collected during 1915-1917 have already been dealt with in a paper written in the fie!d during the East Africa Campaign*. The present paper deals with some 290 specimens, of which 286 were collected by the writer or his native collectors during the years 1918-1923. Some few earlier captures are referred to but not included in the figures.

The present collection contains representatives of all the East African families. 34 of the 54 genera, and 57 of the 140 recorded species. These numbers are distributed as follows:-

\begin{tabular}{|c|c|c|c|c|}
\hline $\begin{array}{l}\text { Family } \\
\text { Tvphlopiılæ }\end{array}$ & …, & $\begin{array}{c}\text { Generas } \\
1\end{array}$ & $\begin{array}{l}\text { Species. } \\
\mathbf{5}\end{array}$ & $\begin{array}{c}\text { No. of } \\
\text { Specimens } \\
23\end{array}$ \\
\hline Glauconidae & ............. & 1 & 4 & 15 \\
\hline Pythonicla & ............. & 1 & 1 & 8 \\
\hline Colubriıla & ............. & 28 & $4 \overline{1}$ & 201 \\
\hline \multirow[t]{2}{*}{ Viperidæe } & ............ & 3 & 6 & 39 \\
\hline & & & Tot: & 286 \\
\hline
\end{tabular}

Only two new species resulted from this material, viz. Typhlops excentricus Procter, and Geodipsas procterce Loveridge, which have beell described elsewhere.

The principal localities mentioned in the following pages are :-

\title{
Kenya Colony.
}

Frere Town, Nairobi, Uasin Gishu Plateau.

\section{Tanganyika Territory.}

Dar es Salcam District.--Dar es Salaam.

Lushoto District.-Usambara Mtns., Gonja.

Moshi District.-Kahe, Garagua.

Arusha District.-Arusha, Longido Mt.

Morogoro District.—Dakawa, Bagilo, Morogoro, Mkata River,

Rudewa, Ilonga, Kimamba Stn., Chanzuru, Tindiga,

Kipera, Madazini, Kilosa, Kideti.

Iringa District.-Rumruli.

Dodoma District.-Pwaga, Itende, Mpanira, Ikikuyu,

Kidenge, Mpwapwa, Dodoma, Suna, Gwao's.

* Loveridgr, "Notes on Snakes in East Africa." Jour. E. A. \& U. Nat. Hist. Soc. No. 13, 1918, py. $315-338$. 
Kondoa-Irangi District.-Mtali's, Mkalama, Zengeragusu, Usshora, Ulugu.

Tabora District.-Tabora, Izikisia, Luguo.

Muanza District.-Sanga, Shanwa, Sagayo, Nyambita, Mwanza.

Bukoba District.-Bukoba, Kabare.

\section{Pontuguese East Africa.}

Lumbo on mainland opposite Mozambique Is.

With six exceptions the identifications were all carried out in East Africa, and I take this opportunity of acknowledging my indebtedness to Dr. G. A. Boulenger and Miss Procter for examining these reptiles and confirming determinations of others. My thanks are also due to Dr. H. A. Baylis and Mr, S. Hirst for determining the parasitic worms and ticks.

As a general rule measurements are not given unless they exceed the maximum given in the Catalogue of Snakes. They are then given in inches, followed by snout to vent and tail measurements in millimetres.

\section{T. Y P I LO P I D E.}

Typhlops mandensis Stejneger.

Blgr. Cat. Snakes, iii. 1896, p. 587.

A single specimen was dug up in some building operations near Government House, Morogoro (23. ix. 17), and brought to me alive. As the species was described from the Isle of Manda oft the Lamu Coast of Kenya Colony by Stejneger as long ago as 1894, and no second specimen has been taken to my knowledge, this new record from the interior of Tanganyika Territory is of considerable interest. It measured $18 \frac{1}{2}$ inches $(463+7)$. Sex $q$. Alive it was almost colourless except for a little buff on the belly, whereas Stejneger's specimen was "Uniform pale greenish grey above, pale buff beneath." I am indebted to Dr. Boulenger for making the identification, and the specimen has been given to the British Museum.

'I'y pillops punctatus Leach.

Blgr. Cat. Snakes, i. 1893 , p. 42.

Three specimens from Dar es Salaam and Tindiga.

The former measured $138+2.5$ and $130+2 \mathrm{~mm}$., with diameter at mid-body of 4 and $5 \mathrm{~mm}$. respectively, so that the diameter goes into the body length 26 to 35 times. Grey above with or without small black blotches and dorsal stripes following the edges of the scale-rows. 
Typulors dinga Peters.

Blgr. Cat. Snakes, i. 1893 , p. 45.

A specimen measuring $33 \frac{7}{8}$ inches $(850+10)$ was caught on 27. xii. 22 at Kilosa, having come above ground after the first heavy downpour of the lesser rains. In colour it was almost identical with the figure in Peters' 'Reise nach Mossambique,' but a week later it was a dark metallic silver, doubtless a sign that it was about to cast its skin.

Typhlops mucruso var. Humbo Peters.

Blgr. Cat. Snakes, i. 1893 , p. 46.

Thirteen specimens from Ilonga, Kilosa, Kipera, Madazini, Kidenge, Mpwapwa, and Usshora.

The largest female of these measured $23 \frac{1}{2}$ inches $(590+5)$ and a male measured $18 \frac{3}{8}$ inches $(460+6)$; it was unearthed by some boys digging a trench at Kilosa on 27 .i. 21 , when I made a note " whitish or flesh-coloured, eyes completely hidden." It had 35 mid-body scale-rows, diameter went 36 times into total length and the tail 77 times.

On 18.ii. 21, having turned the "colourless Typhlops" out of the earth where I had been keeping it, I was astonished to find that it was now the colour of ordinary Kilosa specimens of var. humbo and the eyes distinct having taken up pigment. I do not know what the explanation was unless that it had sloughed just before capture and pigmentation was delayed in the new skin, but I am perfectly certain that there was no trace of the eyes on 27.i. 21, as I examined it very closely with a lens believing I had something new. As the visibility or otherwise of the eyes is an important key-character this is rather interesting.

The coloration was now as follows:-Black above, marbled or speckled (the specks being sometimes confluent) with pale bluish grey. Beneath, the pale blue is about equal to the black in extent. A young specimen had the pale blue brighter, almost bluish slate. It is the constant colouring of all my specimens from Morogoro, Kilosa, and Mpapua.

The eye in my specimens is partly under the præocular, not as shown by Peters* or figured by Sternfeld $\dagger$ for $T$. mucruso. Both these authors show one scale (præocular) between the ocular and the nasal in forma typica, whereas in specimens of var. humbo from 'Tanganyika Territory there are distinctly two. In one young specimen the nasal is in contact with its fellow behind the rostral, and nearly so in the adult mentioned above.

The Usshorn specimen was swallowed by a Bird Snake (T. kirtlandii) with which it shared the vivarium.

* Peters, Reise Mossamb. iii. p. 95, pl. xiii. fig. 3 .

+ Sternfeld, Fauna der deutschen Kolonien, Reihe III. Heft 2, p. 12, fig. 8. 
Typhlops excentricus Procter.

Procter, Ann. \& Mag. N. H. ser. 9, vol. ix. p. 685, June 1922.

As only the type-specimen was taken during the two years I resided at Kilosa it must be decidedly uncommon.

\section{G L A U C O N I I D}

\section{Glauconia distanti Blgr.}

Blgr. Cat. Snakes, i. 1895 , p. 62.

As the type-locnlity of this species is Pretoria it was somewhat of a surprise to find it so far north, but Dr. Boulenger hi:s kindly exsmined the Morogoro specimens for me. 'Thirteen specimens in all were taken from Morogoro and Kilosa.

The largest measured 6 inches $(139+12)$, but the largest of six Kilowa snakes was only $3 \frac{3}{6}$ inches $(78+6)$.

The tail of the type was included 12 times in the total length, but the range of Kilosa snakes is from 9 to 13 times, one specimen having a boily length of $65 \mathrm{~mm}$. had a tail $7 \mathrm{~mm}$. long. The diameter of the body into total length ranges from 48 to 56 as against 65 times in the type. Whilst the type had five lower labials, two Kilosa snakes have four and three others only three!

\section{Glauconia merkeri Werner.}

Wern. Jahresh. Ver. Nat. Württemb. lxv. 1909, p. 61,

A single female from Mtali's, Mkalama Dist., where it was found wriggling on the surface of the ground beneath a fig-tree about 9 p.m. on 10.x. 22 . The species is, I believe, only known from the types which came from Moshi much farther east.

My specimen is a female and is larger than the type by $52 \mathrm{~mm}$. Length of hend and body $212 \mathrm{~mm}$. Length of tail $15 \mathrm{~mm}$. Diameter of boily $3.5 \mathrm{~mm}$. The diameter, therefore, goes 64.8 times into the total length as agninst 80-87 times in the types. 'The tail goes 14 times as against $11 \frac{1}{2}-13 \frac{1}{2}$ times in the original spocimerss. It has 4 upper labials.

The colonr is unifor'm blackish, the borders of the scales lighter. Pupil red with a black ring.

Gladconia emini Blgr.

Blgr. Cat. Snalkes, i. 1895 , p. 64.

A specimen found in a heap of dry manure on the golf links at Dar es Salaam, 4. xii. 22, agrees with Boulenger's description of G. emini except in the following points:-

(i.) Flesh-colour. In life, lowever, semi-transparent, the dorsal scales being minutely stippled with brown, the beily scales quite transparent. $\Lambda$ pinkish tinge imparted to the whole by the blood-vessels which can be plainly seen. 'The type of $G$. emini 
uniformly blnckish, similar to specimens collected by the writer at Nairobi, but there is a specimen from Kosa Kola, Lake Nyasa, in the British Museum, which is also pale tending to orange on the back and has been referred to $G$. emini by Dr. Boulenger.

(ii.) Posterior botder of the rostral does not nearly extend to the level of the eyes as against " not extending quite to the level of the eyes." In the Catalogue description the Lake Nyasa specimen is like mine in this respect also.

(iii.) The diameter of the body goes 57 times into the total length as agninst 50-55 times.

I think there is no doubt, however, that I am correct in referring my specimen to $G$. emini, which has already been recorded from the extreme west of the Territory, the type-locality is Victoria Nyanza. The present record shows that its range extenils right to the coast in the east.

Length of hear and bory $102 \mathrm{~mm}$. Tail $13 \mathrm{~mm}$. Diameter of body $2 \mathrm{~mm}$. The length of tail goes $9 \frac{1}{2}$ times into the total length.

\section{Glauconia longicauda Peters.}

Blgr. Cat. Snakes, i. 1895, p. 66.

Four specimens taken at Lumbo, Mozambique.

The longest of these measured $4 \frac{3}{4}$ inches $(110+12)$, all were females. This snake is far more slender than an average earthworm and of a very transparent flesh-colour. All were taken among the roots of bushes when some land was being cleared of stumps for a camp site.

One which was brought to me in the early morning was dropped into a cigarette tin contrining several Lycophidium semiamulis and Aparallactus capensis from the same habitat. On opening the tin about $6 \mathrm{p} . \mathrm{m}$. the worm snake was found to be missing, but by holding up the other snakes to a strong acetylene light it was lncated in the stomach of a Cape Black-headed Snake. It was the work of a few minutes to chloroform the latter, but the worm snake was already too far digested to be worth preserving.

\section{P Y THON I A}

Pytuon seb Gmel.

Blgr. Cat. Snakes, i. 1893, p. 83.

Eight, specimens, Rumruli, Ilonga, Chanzuru, Kilosa, and Usishora.

Three of these were young specimens sent me by Mrs. Billinge of Rumıuli, Iringa, who wrote that the ratives had killed a female python, whose unstretched skin measured $20 \mathrm{feet}$, and which had 34 young ones with it. She adds that the natives never attack 
the pythons unless they have first taken a dog or goat-kicl, and to judge by the number of pythons so killed they must do an appreciable amount of damage in the district.

A native youngster coming up from Kilosa village heard an outcry by the roulside which he thought was a young kid. Parting the grass about a bush he siaw a linge python which was sivallowing a reedbuck. He took me to the spot, which was a very likely one, but the. python had gone; I think it was more probably a young bushbuck that was taken.

Many parasitic worms were found in the stomachs of my spacimens, viz, Bothridium pythonis Blainv., Polydelphis attenuatc Mol., Aphidascoris filarice (Duj.), and other indeterminate immaturo Ascarids. A larval Filarian was also found coiled up in pimples which it causes on the skin. Snakes so affected rapidly lose their glosiy and iridescent appearance, refuse to feed, and succumb within a fow months. The disease appears to bo infectious to the extent that another snake introduced into the same cage, after the removal of the dying snake, became infected.

\section{OL U B R I X.}

'Tropidonotus olivaceus Peters.

Blgr. Cat. Snakes, i. 1893 , p. 227.

Four speoimens from Dar es Salaam, Bagilo, and Kabare. Found in swampy grass-lands and along river-banks.

All the specimens were rather small. A Dar es Śalaam female, kept in captivity, laid eight eggs measuring $17 \times 8 \mathrm{~mm}$. on 15. vi. 18. A Bagilo specimen killed 22. vii. 21 had three eggs in the ovary measuring $22 \times 6 \mathrm{~mm}$., this was an extremely small specimen measuring $262 \mathrm{~mm}$. in hend and body; the tip of the tail was missing, as is often the case with snakes of this species. It would be interesting to know what enemy it is that deprives them of their tails.

Bagilo specimens have the borders of the ventrals bright mauve and not olive.

'The Dar es Sulatam snake swallowed two frogs (Rance nutti), hind-legs first, on 22. vi. 18, and another, head first, on 24. vi. 18.

Boodon lineatus Dum. \& Bib.

Blgr. Cat. Snakes, i. 1893 , p. 332.

Thirteen specimens from Mkata River, Kimamba, Pwaga, Ikikuyu, Gwao's, Sanga, Shanwa, Tabora, and Bukoba.

The House Snake is usually found about the habitations of man, among rubbish in outhouses, under old sacks, or benenth sheets of iron in the open. It is not infrequently met with crossing paths, and when detected doing so it usually remains 
perfectly motionless until very closely approached. One large specimen on path entered a fissure in black cotton soil and on being dug out disgorged a large rat (Rattus coucha microdon).

A bright orange-coloured specimen was met with at Dodoma (I accidentally trod upon it in coming out of my room). I have never met with an orange variety before, and it faded to strawcolour when preserved. Young specimens tend to be rufous and have fine reticulations which disappear in the adult, which is plumbeous in most of the above specimens.

The reason for their frequenting houses is to be found in their almost exclusive diet of rodents. One such specimen had swallowed a rat and was found with a foot of its tail hanging out of a crevice in the stone basework of the house. The snake was so wedged in that the stone masonry had to be removed hefore the snake could be extricated. A 2 feet 8 inch snake at Gwaos, with greatly distended stomach, held two unstriped grass rats (Arvicanthis abyssinicus neumanni) in its stomach.

On a kopje at Tabora I came upon a Striped-bellied Sand Snake swallowing a young House Snake. When I appeared the Sand Snake disgorged its prey, which I put in my pocket, but found it dead on reaching home, presumably killed by the venom of the back-fanged species.

Ticks (Aponomma lave Linn.) were found in one Kilosa specimen.

\section{? Lycopindium acuTinosire Günth.}

Blgr. Ciıt. Suakes, i. 1893, p. 338.

The rlay before sailing from Dar es Salaam (25.v. 23) I encountered a snake on the sea-front road by the golf links; it was holding its snout downwards, after the manner of an Atractaspis viper, and pushing against a fragment of coco-nut shell as if seeking shelter beneath it from the sun. The snake showed no sense in pushing round and round the fragment. 1 confess I mistook it for $A$. rostrata, picked it up by its stumpy tail, dropped it in a bag, and sent it on board.

I did not examine it again until the second day at sea, when I found it not only dead but very decomposed. Close examination showed at once that it was a Lycophidium, and according to Boulenger's key* it was $\boldsymbol{L}$. acutirostre, hitherto only known fiom Zanzibar Is. As I was unable to count the ventrals or compare it with the full deseription, I have marked the determination with a query. The specimen was too decomposed to preserve.

It seems to me from its striking superficial likeness to Atractaspis rostratc that this species of Lycophidium has adopted similar burrowing habits, and it may be on this account that it is so rarely met with, less than a dozen specimens being known I believe.

* Boulenger, "A List of the Snakes of East Africa . . etc." P. Z. S. 1915, p. 620. 
Lycopiimium semiannulis Peters.

Blgr. Cat. Snakes, i. 1893, p. 339.

Eight specimens were taken at Lumbo, where they lived in the surface soil amongst the roots of grass.

The largest male measured $7 \frac{3}{4}$ inches $(170+21)$ and female $9 \frac{3}{3}$ inches $(203+35)$. None of the specimens attempted to bite when handled.

LyCophidium CAPENSE Smith.

Blgr. Cat. Snakes, i. 1893, p. 339.

Two specimens from Kilosa, found on paths.

The largest specimen I have yet come across wns taken at Morogoro, $18 \frac{3}{8}$ inches $(405+52)$.

A nematode (Physaloptera sp.) was taken from a Kilosa snake

\section{LycopHidium JaCKSONII Blgr.}

Blgr. Cat. Snakes, i. 1893, p. 340.

A single specimen was taken in a tent at Longido after a night of heavy rain. The type-locality is Kilimanjaro, so the present, record of this rare snake extends our knowledge of its westward distribution somewhat.

It was taken in the act of attempting to swallow a skink (Lygosoma ferrandii), which was rather a big mouthful for it.

Simocephalus Nyass E Günth.

Blgr. Cat. Snakes, i. 1893, p. 347.

A single specimen at Lumbo during the demolition of a termite hill. Female 22 inches $(433+122)$.

Cirlonornis neglectus Peters.

Blgr. Cat. Snakes, ii. 1894, p. 94.

Five specimens from Nairobi. As a variant from its usual habitat one put its head out of a leather hair-brush case, having reached the dressing table from an open window.

One was seen swallowing a frog-its usual diet-but anothei had no less than three skinks (Ablepharus vahlhergii) in its stomach.

An immature ascarid was also found in one specimen.

Chlorophis irregularis Leach.

Blgr. Cat. Snakes, ii. 1894, p. 96.

Single specimen from Bukoba, collected by Mr. N. C. Miller. 
Philothamnus semivariegatus Smith.

Blgr. Cat. Snakes, ii. 1894, p. 99.

Twelve specimens from Dar es Salaam, Ilonga, Kimamba, Kilosa, Kabare, and Lumbo.

None of these exceeded in size a female from Morogoro, measuring $51 \frac{7}{8}$ inches $(837+466)$, taken 25 . xi. 17 , One specimen had only 149 ventials and two had 159 sub-caudals.

The coloration of Lumbo specimens was strikingly different from the grass-green examples, of which a long series were taken previously. In Lumbo specimens the head and neck were pale green; body mauve; both freely speckled with blnck. The tail was plumbeous; thront china-white; belly and sub-caudals whitish with a mauve tint. Ventral keels of a mauve colour. The tongue at tip and base was black, but the middle portion bright Cambridge-blue. All four specimens taken at Lumbo were the same.

Attracted by the outcry raised by birds, I captured the Frere Town specimen whilst it was descending the almost vertical treetrunk, taking advantage of every irregularity in the bark.

A Spotted Wood Snake was found swallowing a gecko (Hemidactylus mabouia) in the fowl-house and only the tail was to be seen. Immediately it was approached the snake disgorged the gecko, and on being seized by the tail inflated the neck and anterior portion of the body vertically, and struck at my hand repeatedly. Here then is another tree-snake with the same habit of inflation when alarmed or annoyed as the Boomslang and Bird Snake.

Another specimen on being caught in a thatch disgorged a gecko of the same species, and a third snake had swallowed a young toad (Bufo regularis).

During a flood one specimen was found on a maize stalk, five feet above the water. A young one was recovered from the stomach of a One-streaked Hawk (Karipifalco monogrammica).

\section{Turasops rotuschildi Mocq.}

Mocq. Bull. Mus. Paris, 1905, p. 286.

A specimen sent me from Bukoba extends the range of this scarce reptile westwards; it was described from British Eust Africa. I have also had the plensure of examining three more specimens collected by Mr. J. A. 'Turner in the Yala River region near Mt. Elgon.

Rifamophis Jacksonil Günth.

Blgr. Cat. Snakes, iii. 1896, p. 632.

One male from Kabare.

A specimen of this snake was killed at Muthaiga, near Nairohi, in 1919, by Mr. A. J. Klein, and is now in the Nairobi Musemm. It measured 7 feet $5 \frac{1}{2}$ inches $(1671+584)$, and eight specimens were collected by Mr. 'Turner on the Yala River. 
I have never seen the resemblance of this sriake to the black phase of Dispholidus typus remarked upon. Their similarity of appearance is extraordinary and when alive they are indistinguishable, except perhaps for the slightly larger eye of the Boomslang - both are tree-snakes and found in the same locality at times. Like all snakes that are large and black they are indiscriminately called "Black Mambas" by the European residents.

Coronella semionnata Peters.

Blgr. Cat. Snakes, ii. 1894, p. 195.

T'wo exnmples from Dar es Sulanm mol Sngayo, Mwanz.

The latter specimen is very juvenile $(210 \mathrm{~mm}$. over all $)$, and has a small scale between the rostral, internasals, and nasals, apparently split off from the rostral.

Coronella schefflen Sternf.

Sternf. Sitzb. Ges. Nat. Fr. Berl. 1908, p. 93.

I have not been so fortunate as to collect this rare snake myself, but a specimen in the Nairobi Museum was oltained by Capt. Rainsford just south of Lake Rudolph in 1918. 'This new record is, therefore, far north of the type-locality Kibwezi on the Uganda Railway.

Grayia tholloni Mocq.

Mocq. Bull. Soc. Pliilom. (8) ix. 1897, p. 11.

Mr. N. C. Miller sent me a specimen for determination which he had collected at Bukoba, 1922.

Homalosoma lutrix Linn.

Blgr. Cat. Snakes, ii. 1894, p. 273.

A single specimen from Kabare, Bukoba, 10. i. 23.

This female, though small $(290+38 \mathrm{~mm}$.), was very bloated, having no fewer than ten eggs, measuring $12 \times 8 \mathrm{~mm}$., in its oviduct which extended forward to the region of the lieart.

Prosyma ambigua Bocage.

Blgr. Cat. Snakes, ii. 1894, p. 248.

Three specimens. One of these was taken in a termite nest at Lumbo; the other two were found in a bottle without data in a German House at Morogoro.

One of these had paired præfrontals and 155 ventral scutes.

DASYPEL'IS sCABRA Linn.

Blgr. Cat. Snakes, ii. 1894 , p. 354.

Six specimens were collected from Kilosa, Kipera, and Zengeragusu in Tanganyika Territory and Lumbo in Portuguese East Africa. 
The Kilosa and Kipera specimens are of the type that appears to be a mimic of Causus rhombeatus, but $C$. rhombeatus is not found at Kilosa, and where this Night Adder is common at Nairobi you get an all-black or all-brown variety of the Egg. eater. The Zengeragusu reptile was a most interesting variety. Colour iron-clad grey with a single row of brick-red dorsal spots.

This snake was literally covererl with ticks (Aponomma lave Linn.), seventy-five of which I collected.

\section{Geodipsas procten ar Loveridge.}

Love. Proc. Zool. Soc. 1922, p. 313.

Since my description of the type a second specimen has been taken in the same locality by my collector.

Male. Snout to vent $350 \mathrm{~mm}$. Tail $70 \mathrm{~mm}$. Mid-body scales 17 ; ventrals 153 ; caudals 40 ; upper labials 8 . This specimen agrees with the type in all essential respects, excepting that the $3 \mathrm{rd}, 4$ th, and 5th upper labials enter the eye as against 4 th and 5 th in the type. It has also 5 more ventrals and 9 caudals less.

The following markings are also distinguishable. A black collar on nape or back of head touching posterior border of parietals, but not reaching to ventrals ; it is very broadly $\mathbf{V}$-shoped. 'I'welve or more black saddle-like markings, two scales deep, on anterior third of body, separated from one another by two-scale intervals which are approximately $2 \mathrm{~mm}$. interspaces. White stipplings on sides of anterior third of body sometimes falling on outer edges of ventrals, which are grey and thus differ from the colouring in the type, as they are very distinct from the blackish dorsal colouring.

'Tarbophis semiannula''Us Smith.

Blgr. Cat. Snakes, iii. 1896, p. 51.

Five specimens from Morogoro and Lumbo.

The Morogroro specimen is so much larger than the dimensions given in the Catalogue that I give it here $-35 \frac{1}{4}$ inches $(735+159)$. A Lumbo specimen had only 198 ventrals.

It is curious how one may be in a locality for many months without meeting with a particular species of snake, and then several turn up within a few days, followed by a long period when none are met with. Such was the case with this species at Lumbo, where I caught two females in one evening and a third a few days later, the circumstances of capture being as follows:At 7 p.m. I was hastily summoned to the Mess, where it appears that the adjutant was about to take his seat when the snake was noticed entwined in the wicker back of the chair. After putting this Tiger Snake into a bag I returned to my tent, and within an hour was summoned to capture a second, which was slowly moving across the arc of illumination cast from a lighted tent. Both were females, and there was only a millimetre difference in their lengths ( 2 feet 6 inches); they were taken about 20C-300 yards apart. 
The larger had ten eggs in the ovary, the smaller nine. Both stomaclis were empty of food, but the one was afflicted with inmature and, therefore, indeterminate worms of the genus Physcloptera, as was also a specimen taken a few days later.

\section{Leptodira hotambaia Laur.}

Blgr. Cat. Snakes, iii. 1896, p. 89.

Two specimens from Garagua and Mwanza.

'The latter had 20 and not 19 scale-rows at mid-body. Instead of the white frecklings usual in East African Herald Snakes it had transverse wavy white lines, one-scale wide, all along the back, which gave it a very Causus-like appearance. When annoyed these Herald Snakes flatten their heads till the white lips can be seen from above; the body is also depressed and flung about spasmodically, giving the rrptile a very viperish aspect.

I have always found them vicious and ready to bite on the least provocation; one specimen introduced into a vivarium where there were already a couple of larger snakes $(P$. sibilans and $R$. oxyshynchus) bit them both, but neither appeared to suffer any ill effects.

\section{Chametortus aulious Günth.}

Blgr. Cat. Snakes, iii. 1896, p. 98.

I have only come across three specimens of this scarce snake in the past eight years: one was much battered in the roadway at Mwomero, another was found, without data, in a bottle in a German house at Morogoro in 1916, and recently (26.iv. 21) a young one at Chanzur'u near Kilosa which had the remains of a gecko (apparently Lygodactylus sp.) in its stomach.

\section{Amplorininus nototenia Günth.}

Blgr. Cat. Snakes, iii. 1896, p. 125.

Two specimens. A young male frorn Kilosa, and a female from Mkata River. The former was crossing open ground, and the latter was twisted into the side of a grais hut, about 6 feet from the ground. In its ovary were two eggs, $12 \mathrm{~mm}$. long (27. viii. 21). In its stomach the remains of a gecko (Lygodactylus picturatus), and it was apparently stalking another which was close to it at time of capture.

\section{Trimerorhinus triteniatus Gïnth.}

Blgr. Cat. Snakes, iii. 1896, p. 139.

Two specimens from Arusha and Nairobi. I take this opportunity of correcting an error of mine when I referrer these specimens to Psammophis brevirestris* Peters. The Nairobi example was taken from beneath a latrine seat! 
A fortnight after its capture it attempted to swallow a dead female Mabuia striata which was put into the cage. The skink was much too large for it, but the snake persavered for thirty minutes, but could not get past the front legs; it finally disgorged the whole. The Arusha specimen had a skink in its stomach when taken. This snake is extremely gentle.

\section{Rhampiniophis oxyrhynchus Reinh.}

Blgr. Cat. Snakes, iii. 1896, p. 146.

Eight specimens, Dar es Salaam, Chanzuru, Kilosa, Tindiga, Pwaga, Dodoma, Luguo, and Mwanza District (1920-22), as against twenty-six from Morogoro and Jumbo (1915-18). Several were dug out of gerbil ( $T$. swaythlingi) holes and one was found occupying the same hole as a mungoose (II. ivorii).

The largest male (whose tail-tip was missing) measured $56 \frac{3}{4}$ inches $(1014+425)$, and largest female 5 feet $(1040+$ 469 ), nearly six inches longer than the maximum mensurement given in the Catalogue. Half-a-dozen specimens had more than 110 subcaudals, the highest number being 116. As might be expected, a specimen from the sandy thornbush country of 1)orloma was very pale sand-colour.

At Kilosa these snakes were pairing during December in 1920. Three very large ones were seen many times in the grass during November, the rains having commenced on the 1st, but it was not till the 4th of December that I surprised a pair in coitu; one of these I crught, and the other the following day. It was about 5 feet long. Ten eggs measuring $40 \times 20 \mathrm{~mm}$. were laid by one of this pair in the vivarium between 1-7.viii. 1921, so that the period of gestation would be about three months. Eight eggs $(15 \times 8 \mathrm{~mm}$. $)$ in a Dodoma specimen taken 11. vii. 21 . I have already recorded 13 eggs laid in October by a half-grown female of this species.

In diet they are omnivorous; a small specimen endeavoured to swallow a large rat, but could not get past the front legs and was forced to disgorge (12.iii. 21), but a large specimen took a young rat (15. 6.21), and a wild specimen disgorged a shrew (Crocidura flavescens) on being caught. The natives saly that a tame guineafowl chicken was taken by the largest of the three snakes which were seen in September. 'The chicken was heard calling in the grass, but as the boys were afraid to go into the grass, it is a matter of supposition. In captivity I feed them on Mabuia varia, which they take well. It might be of interest to herpetologists to know that a snake should not be fed on recently chloroformed fond. Wishing to pack some of these snakes to go to Europe I chloroformed some geckos and skinks and introrluced them into the mouths of the snakes, which swallowed them, but a few moments later showed signs of poisoning, one rolling on its back.

The bite of this species would not appear to be dangerous to human beings, as a small native boy who caught a 4 -foot snake 
was much bitten on the hands (which bled freely), but suffered no ill effects. After the first excitement, incidental to capture, they settle down to a life of confinement and are the gentlest of snakes.

I found a young specimen in the stomach of a hawk (Butcistur. rufipennis) at Morogoro on 31.i. 18.

Parasitic worms (Pilaria sp.) were found encysted in the skin. Ticks (Aponomma lave Linn.) were found on a Kilosa snake (20. v. 23).

\section{Psammophis subteniatus Peters.}

Blgr. Cat. Snakes, iii. 1896, p. 160.

The Stripe-bellied Sand Snake called Sangaraza in Kiswahili is so widely distributed that I have not troubled to catch many this tour, as forty-six were collected in 1915-19; about a score were taken 1920-22 from many fresh localities near Dakawa, Mkindo Mkata Stn., Ilonga, Kimamba, Chanzuru, Kilosa, Itende, Kideti, Suna, Mtali's, Sekenke Rd., 20 miles from Mkalama, Usshora, Wembere, 'Tabora, Sanga, Lalago, Sagayo, Nyambita, and Lumbo.

This snake is an expert climber; one flashed across my path and was 20 feet up in the topmost tivigs of a stunted tree in a moment. My attention was drawn to another five feet up in $n$ maiombo bush, but so well did it blend with its surroundings that I could not distinguish it until it mover, though I was within ten feet of it all the time. I caught several in the thatches of native huts, where they had gone in search of skinks I believe.

My largest male mensured $49 \frac{3}{4}$ inches $(861+399)$ and female $45 \frac{3}{4}$ inches $(775+383)$. Both from Morogoro.

Whilst the colouring in specimens from one locality seems constant, a great deal of variation occurs between examples from different localities. The characteristic black ventral lines were indistinguishable, except with the closest examination when traces could be seen, in the Kidete specimen collected by Mr. C. F. M. Swynnerton. Four snakes from Mtali's had pure white instead of deep yellow bellies. At Suna the coloration is adapted to the sandy thornbush in which they live, and which seems to influence the coloration of its typical mammals and, to a less extent, birds.

This species will eat mammals, birds, snakes, and lizards. A specimen taken at Frere Town after a hard chase was placerl in an ordinary small biscuit tin, about $8 \times 5$ inches in size. The following day a native brought me a Warbler (Prinia mystacea) with its head almost knocked off, this I dropped into the tin, and on opening it the following day found a bulge in the snake and no visible bird. This freshly-caught diurnal snake harl eaten a damaged dead bird in the darkness of a small tin on the day succeeding capture. 'Ihere is no saying what a snake will do.

'The following note-was made at Kimamba on 15. viii. 21 : 
"Between 5.30 p.m. and sundown I saw a Stripe-bellied Sand Snake lying in the roadway; three times I disturbed it and it returned each time. I noticed that a number of the Small Weavers (Lagonostictc sp.)were picking up grass seeds and hopping about unconcernedly close to it. I think one might assume that the snake was lying there with the object of securing a bird."'

I have alleady mentioned under $B$. lineatus how one of this species was found swallowing a young House Snake at 'Tabora.

'Their commonest food, however, is the striped skink, and this they very soon dispose of, as the following timing will show :-

12.44.50. Snake seized skink.

12.47.10. Head of skink was in throat.

12.48. Hind-legs enveloped.

12.48.10. Tail disappears.

There is usually a pause for rest after the body has passed into the gullet, and the tail of the meal sticks out of the snake's mouth as if it har been having an after-dinner cigar!

At Frere Town (1. vii. 19) my attention was drawn to one of these snakes which appeared to be playing. When first seen it was stretched out at tull length excepting that its head was turned round in the direction of its tail. It then passed its head beneath its body, then over the back, then beneath the body again, and so on, traversing its own length towards the tail. 'This was not done hurriedly, but in dallying fashion, with occasional withdrawing of the head. Unfortunately, a native running up at this moment disturbed it, so that I was unable to see the end of the performance.

At Kilosa a captive specimen was seen to rub first one side of its mouth against its side, then the other side of the mouth against the opposite side, repeating the operation a score of times as it slowly worlied along its own length to the tail. I feel sure this caressing movement was only play. Having reached the tail it moved slowly away in the grass (Kilosa, 2. v. 23). This snake, nearly 3 feet in length, was killed and three-quarters eaten by a baby lemur (Galago panganiensis) occupying the same large roomy cage (Kilosa, 4. v. 23 ).

At Lumbo camp I often wondered what chance a snake would have of being in the camp without my being informed by one of the hundreds of natives employed about the place. With the object of deciding this I released a Stripe-bellied Sand Snake near my tent. This tent was situated beneath a mango and a coco-nut palm, but had a cleared space of tifty yards of sand on three sides of it, on the fourth side were several buildings. The snake was caught by me on a railway embankment half-a-mile away, escaped, and was recaught by the reed fence enclosing the tent. Next day I liberated it at 6 a.m. At 8.30 a native came running to say a snake was in his tent, which lay a little more than fifty yards to the west of mine, and was the first cover in that direction after crossing the open sand. I recaptured it and

Proc. Zool. Soc.-1923, No. LVIII. 
á week later released it at 11 a.m. At 1.30 p.m. a European corporal hurried up requesting me to catch a snake which was under his bed; the marquee in which he slept was due north from my tent. A week later $I$ again released it at 6 a.m. and at $8.45 \mathrm{a} . \mathrm{m}$. found a man trying to head it off from entering a patient's marquee, almost due south from my tent and the first cover in that direction. It had now tried in three different directions, which was rather remarkable, and had been apprehended at the first tent in the direction taken. Twice more I liberated it, the last time at 10 p.m., to give it a night's start, and I saw its tail disappear beneath my bed. As I heard nothing more of it for a fortnight I thought it had at last won clear of the camp, but on Oct. 10 it was found at noon in the tent of some A.N.M.C. boys, one of whom struck at it with a stick, so injuring it that 1 killed it and threw it into a case of Lesser Mungoose (Helogale ivorii Thos.), one of which seized it, first crumcherl its head, and then swallowerl it whole. T'his snake had a portion of its tail missing, so it was unnistalialole. I concluded from the results of this little experiment that I marle a pretty exhaustive snake survey of the area covered by the camp when I collected sixteen species in it during five months.

Many kinds of worms were found in the stomachs of various specimens, including two new species in a Mombasa snalie, viz., Oochoristica crassiceps Baylis, and Ophidascaris mombassica Baylis. Physaloptera affinis Gedoelst, from a Kilosa specimen. Physaloptera sp. and Ascaris sp. from Mombasa specimens. I am of the opinion that these worms may cause the death of the host, for in two instances the snake turned over and over and died. In the case of the Mombasa snake the feet and claws of the Prinia it had eaten just a month before were still in its stomach.

\section{Psammopins sibilans Linn.}

Blgr. Cat. Snakes, iii. 1896, p. 161.

Nine specimens from Chanzuru, Kilosa, Wembere, and Lumbo

Largest male $588_{8}^{3}$ inches $(1120+362)$ and largest female $59 \frac{1}{2}$ inches $(1100+404)$, but the tail tip is missing. The tail is proportionately longer in the females of this species. Both these records are of Morogoro specimens, being the best of seventeen specimens collected 1917-18.

This snake feeds upon both mammals and reptiles, a very large mouse being taken from the stomach of one snake and several records of geckos (H. mabouia) being taken by them.

The eagle in whose gullet a full-grown specimen was found has since been identified as the Black-breasted Harrier Eagle (Circaëtus pectoralis Smith). I have since taken a younger snake in the stomach of another species of hawk.

At Lumbo (19. viii. 18) some natives killed a fine Cobrä ( $N$. nigricollis) in the act of swallowing a large Hissing Sand Snake. The cobra measured $50 \frac{1}{2}$ inches and had already swallowed 
28 inches of the sand snake whose body measured $33 \frac{1}{2}$ inches; unfort,mately, in the excitement of killing the cobra the greater part of the tail of the sand snake had been cut off, but other specimens of this body length had tails of between 12 and 13 inches, so that, a $50 \frac{i}{2}$-inch snake was engaged in swallowing a 46 inch snake and would doubtless have succeeded.

From one of these Lumbo snakes I removed three worms (Polydelphis quadricornis Wedl.) which measured $14 \mathrm{~mm} . \times 6 \mathrm{~mm}$. A Morogoro specimen, which was ailing and would not feed, spued up a quantity of watery and slimy matter on the morning of 9. iv. 18 and died the same evening. There were no visible parasites in the stomach, but one lobe of the liver appeared to be full of cysts.

When crossing the Wembere Flats (9. xi. 21) I came upon a sand snake at $8 \mathrm{a} . \mathrm{m}$. that was apparently dying of thirst. It offered no resistance to being picked up and died shortly afterwards. The stomach was clean and empty. It had dusky ventral stripes like the brighter ones of $P$. subtconiatus.

\section{Pasamorhis bisemiatus Peters.}

Blgr. Cat. Snakes, iii. 1896, p. 168.

'Three specimens from Kahe, Ikikuyu, and Dodoma. This species seems partial to sandy or rock-strewn desert country. The Dodoma snake, though only measuring $12 \frac{3}{4}$ inches, had a skink (Lygosoma ferrandii) in its stomach, as had also the Ikikuyu specimen.

\section{Psammophis angolensis Bocage.}

Blgr. Cat. Snakes, iii. 1896, p. 170.

Six specimens from Kilosa and Izikisia, and two which were without locality in a bottle at Morogoro, at which place they were probably taken. Three were taken on paths and one twisted into the grass of a banda five feet from the ground. This last had nine upper labials on the left lip, the right having the normal number of eight.

\section{'T'HeLotornis KirtuAndiI Hallow.}

$$
\text { Blgr. Ca.t. Snakes, iji. } 1896 \text {, p. } 185 .
$$

One specimen from Zengeragusu, also seen at Lumbo.

'The largest Morogoro specimen measured $58 \frac{1}{4}$ inches $(919+$ $548)$; the Zengeragusu female is $53 \frac{5}{8}(933+415)$.

'The Morogoro specimen laid 8 eggs on 16.i.18. These meisured $27 \times 15 \mathrm{~mm}$. The yellowish parchment-like shells were irregular in outline with many concavities. They were lair singly at intervals of five to ten minutes. The Zengeragusu snake laid two eggs on 24 . xii. 21 which were dry when found, they then measured $38 \times 15$ and $34 \times 14 \mathrm{~mm}$. respectively. As the 
snake escaped the following day it is probable she would have laid more.

This is an essentially arboreal species and offer's one of the finest examples of cryptic colouring amongst East $A$ frican snakes. 'The long and slender body is vine-like in its proportions, and coloured for the part. In Morogoro specimens the crown of the head was lenf-green and not unlike a leaf in shipe ; the Zengeragusu snake liad the crown of its head the same colour as the body however. The tongue is bright red with a black tip. When annoyed or scared they inflate their throats vertically like a Boomslang does.

I havealready mentioned the swallowing of a T'yphlops mucruso by this Zengeragusu snake in captivity. Two months after its escape it was killed in a tree only 200 yards from its cage and then had a Chamceleon dilepsis in its stomach.

\section{Dispholidus rypus Sinith.}

Blgr, Cat. Snakes, iii. 1896, p. 187.

Two specimens of the Boomslang or Ngole, as it is known in Kiswahili, were taken at Kilosa and Lumbo respectively.

The largest male measured 56 inches $(1027+393)$ and female $69 \frac{1}{4}(1269+489)$, the latter being $258 \mathrm{~mm}$. longer than the maximum given in the Catalogue. 'I'hese two snakes wero the finest of a series of eleven collected at Morogroro. Of the two snakes under consideration, the Kilosa one was bright green and the Lumbo snake brown.

In captivity they ate sumbird, wagtail, weavers (Ploceus, Urreginthus, Lagonostictc), warbler, bulbul, and swallow. The Kilosa snake when shot had the remains of a black swallow (Psalidoprocne sp.) in its stomach.

The Lumbo Boomslang, 68 $\frac{1}{4}$ inches in length, had a chameleon (C. dilepsis) in its stomach. At Morogoro a Brown Boomslang: fell out of a tree in the avenue, together with a chameleon. A green Boomslang and a chameleon of mine escaped, and later I recaptured the snake close by with what was probably the same chameleon in its mouth. A few days later a second brown Boomslang fell out of the same trees with a chameleon. All these incidents occurred within a month of each other, showing that though the Boomslang may like a chameleon diet it has considerable dificulty in mastering its prey, seeing that no fewer than three fell out of trees while attempting to do so.

I therefore introduced a chameleon into the cage of a very large and black Boomslang. The snake immediately approached the chameleon, sliding silently towards it with raised head; the chameleon thereupon raised its occipital flaps, inflated its throat, and swayed about from side to side, suddenly lunging forwards with widely gaping mouth and uttering a hiss. I then removed the chameleon from the cage, but fed several snakes on chameleons later when pushed for other food. 
Calamelaps poly hepis Bocage.

Blgr. Cat. Snakes, iii. 1896 , p. 246.

Two specimens, one dug from a termite mound at Lumbo, the other found in a bottle at Morogoro without date, but as all the other inaterial in the bottle was local I have little cloubt that it was collected in Tanganyika Territory. This species is only known from Nyasaland and Angola before.

Lum bo male measured $17 \frac{7}{8}$ inches $(405+47)$. Scales 19,176 , 30,6 . 'The maximum number of caudals given in the Catalogue is 27 .

Rimocalameí meleagris Sternf.

Sternf. Mitt. Zool. Mus. Berl. iv. 1908, p. 244.

Found on a path at Gonja (29. v. 16), measures $11 \frac{5}{3}(269+25)$; originally described from Lamu Is., K.C. I believe the identification to be correct, though the number of ventral scutes cannot be determined as the snake was stepped on and slightly damaged. It has 15 scales at mid-body, 28 subcaudals, 7 labials, and was presented to the E. A. \& U. Nat. Hist. Society at Nairobi, in whose museum it now is.

Aparallactus Jacisonit Günth.

Blgr. Cat. Snakes, iii. 1896, p. 256.

The longest of five specimens collected at Longido West measured $10 \frac{\pi}{8}$ inches $(228+48)$.

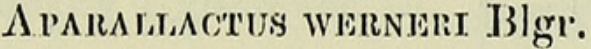

Blg1. Cat. Snakes, iii. 1896, p. 257.

Single individual from Bagilo, Uluguru Mts., measured $10 \frac{1}{2}$ inches $(203+45)$.

Aparallactus capensis Smith.

Blgr. Cirt. Snakes, iii. 1896, p. 259,

Seventeen specimens collected at Luinbo about the roots of grass or shrubs, or on the surface of the sandy soil in the early morning. The largest of this good series was $47 \mathrm{~mm}$., less than the maximum given in the Catalogue.

Earlier in this paper I have referred to a worm snake being eaten by this species in continement,

Elapechis guentheri Bocage.

Blgr. Cat. Snakes, iii. 1896, p. 359.

One female from Nairobi (21. viii. 19) measuring $23 \frac{3}{4}$ inches $(545+43)$, in whose stomach were four lizard's eggs measuring $8 \times 4 \mathrm{~mm}$. Is it possible that the snake had swallowed a pregnant: lizard and that the gastric juice had not acted on the covering of the eggs? 
Elapechis Niger Gïnth.

Blgr. Cat. Snakes, iii. 1896, p. 359.

A single specimen from an ant hill at Lumbo; another was. killed but hadly smashed in the same hill. I also encountered a third specimen in November 1920 just before dusk on the Uasin Gishu Plateau near the Burnt Forest. I held it down with my cycle pump till I had had a good look at it. As I lad lost my way I had other things to think of than its preservation, and so released it. Lumbo temale $20 \frac{1}{2}$ inches $(488+32)$ with 142 ventral scutes.

Naia nigricolitis Reinh.

Blgr. Cat. Snakes, iii. 1896 , p. 387.

Twelve specimens of the Black-necked Cobra, known as Kigau in Kikami and Fera in Kiswahili (not Pili as given in sundry dictionaries, which is the Puff Adder), were met, with at Morogoro, Rudewa, Kilosa, Mtali's, Tabora, Mwanza Dist., Frere Town, Nairobi, and Lumbo.

The Lumbo specimens are referable to Peters' var. mossambica, Nairobi ones to forma typica. Mtali snake was all black with no throat markings. Mwanza Dist. example was black above, mottled black and white beneath, no red on throat. f'abora specimen had the throat red-banded, being young it was plumbeous above. I came upon it as I was clambering over a kopje, and it came straight for me for the best part of a yard with hood spread, spat at me, then turned into a crevice, which was the reason it. approached, "home" being between us. It struck me that the red and black bands on the throat are obviously "warning colours."

It is curious that of a score of specimens collected all have been females hitherto ; one had 180 and another had 181 ventrals, two had 51 and two 53 subcaudals.

During September 1920 an Indian juggler who had a captive cobra brought me ten eggs measuring $35 \times 17 \mathrm{~mm}$. recently laid by it. The eggs are usually deposited in old termite hills.

Mammals, birds, reptiles, and amphibia are alike included in the dietary of this species, and no doubt this fact explains its wide distribution and numbers. On arriving at Frere Town (17. v. 18) I was informed by my host that he had been much plagued by a cobra in his fowl-house. During the three previous nights it had killed six pigeons, two pigeous, and one pigeon respectively. At seven o'clock that evening I received a message that the cobra was now in the fowl-house coiled among the rafters about twelve feet from the ground. On arrival I saw a capture was impossible and sent back for a $410 \mathrm{gun}$, from which I delivered a charge of No. 10 shot. The concussion in the small iron building made such a dust that we had to retire : a flop, and down fell the cobra at our feet still writhing and striking this way and 
that. It measiured $64 \frac{1}{2}$ inches, and in its stomach was a young pigeon, whilst two pigeon's eggs were in its gullet.

'Twelve days later, just after dark, there was another great outcry amongst the poultry, and my host running out with a stick surprised a $66 \frac{1}{2}$-inch cobra swallowing a chicken, taken thus at a disadvantage it was easily dispatched. It was of course stated that it was the mate of the first, come in search of its fellow, but unfortunately for this popular belief both were females.

At Morogoro, a native brought me a chicken coop containing one dead cobra, one fowl ditto, and three chickens, one of which was headless. A few days before, this snake was supposed to have taken three chickens from the same coop. This time the boys hearing cackling ran out and killed the snake, but not before it had bitten the fowl and her brood. Opening the snake I found one chicken in its stomach and a chicken's head in its gullet, and so surmise that it was in the act of swallowing it when struck by the boys, who probably knocked off the chicken's body in their attempts to strike the snake's head. Length 51 inches.

I have already spoken of a cobra killed whilst swallowing a sand snake. I have known one to eat four toads (B. regularis) in a fortnight, another three in one day, and a still more remarkable cnse of gluttony occurrerl at Morogoro. I went out with a lamp and put two toads in the snake's enge, which was occupied by a half-grown cobra only. It seized the first toad and on my return was chasing the other round the cage with the first in its mouth; it struck at it again and again, but of course without effect. It then paused and swallowed very energetically. When the first was disposed of the second was bitten in the abdomen, held for half-a-minute, then released, but as it began to hop it was seized by the hind leg, and for nearly twenty minutes the cobra attempted to swallow it hind end first. At the end of that time it took the head in its mouth and swallowed it with ease. Precisely the same thing occurred with the third toad, which speaks badly for the reputed intelligence of the cobra. $\AA$ fourth and fifth toad followed, but I did not stay to witness their engorgement. Six days later this half-grown cobra had resumerl its normal proportions.

Its dietary leads it to frequent the haunts of man, where it is frequently found in sheds, fowl-houses, rubbish heaps, and tents. In the bush they prefer to take up their abode in termite heaps, upon which they lie and bask in the morning sunshine.

I know of a family residing near Nairobi in which nearly every member, and many of the employees about the farm, have been spat at in the eyes at one time or another. I wish to emphasise this point that the cobra deliberately aims at the face, as only the other day I read in a journal that it was a matter of accident when the venom reached the eyes. The lady of the household referred to, on going to the fowl-house, where it was none too light, saw something dark in one of the boxes, and supposing it to be a fowl she bent over it and received a charge 
of venom full in the face, the resultant shock and pain was so severe that she sank down on her knees and called for help.

I'his cobra rarely bites, so the following case, which occurred at Kilosa on 26.v. 21, is of interest. A very intelligent native in my employ was returning home one evening at clusk (6.30 p.m.) when he stubbed his foot against what he thought was a stick lying across the road. Next moment with a short hiss the cobra launched at him and struck with both fangs just above the left ankle-his feet being bare of course. The snake withdrew immediately and set off in the direction of the railway line; he ran after it, and the snake rose and spread its hood; he looked about for a stone, but his friends called to him to withdraw or he would get bitten again. He rejoined his companions, and very soon began to feel sick, so he went to a native (Wanyimwezi) "doctor," who first applied a ligature above the knee and then made from nine to a dozen horizontal incisions above the site of each fang-mark, i.e. between the bite and the heart, and into these rubbed some "medicine."

Ramazan was taken home by his friends, and on arrival ate some mealie-meal (usual evening food), but threw it all up. Every time he attempted to eat the following day he was unable to keep anything down, and he said he felt successive waves of venom come up from the leg as far as his throat and then recede again. By the 28th he was well enough to return to work.

I met a weird old "snake charmer" in Mwanza Dist. who had in his possession a 68-inch cobra, which he kept in a small bark basket. 'The first time I saw him playing with it, the snake slid out when he came to put it back in its box; this happened two or three times, and he slapped it on the head, when, quick as thought, it apparently attempted to spit in his face (and as he was stooping over the box his face was not two feet from the snake). I was within four feet myself and remarked that no venom accompanied the open-jawed hiss, and he replied with a laugh that the venom was finished. He elected to become a camp follower for a small consideration. A few lays after, when he was holding his daily display - tying the cobra round his naked waist or wrapping it two or three times round his neck and flinging its head over his. shoulder, so that it struck his back with a resounding whack, - my curiosity was so piqued that I bought it from him and chloroformed it. 'The poison teeth and parotids were intact!

Among the parasites of this snake were worms (Dicuphanocephalus simus Daubeney 1923 and Polydelphis quudricornis (Wedl.), also ticks. The tick (Aponomma exornatum) was taken on a Nairobi cobra.

NAIA maIe Linn.

Blgr. Cat. Snakes, iii. 1896, p. 374.

Though this snake ranges from Arabia and the borders of the Sahara northwards to Zululand, neither Tornier nor Sternfeld give any definite localities in Tanganyika Territory for the 
Egyptian Cobra, and the present specimen from Kilosa is only the second which I have come across. It was shot by Capt. Turnley beneath a rock in a dry ravine called Mbweni and is now in the Game Dept. collection.

Male just under 6 feet $(1475+325)$. Scales $17,108,69,7$; the second lahial on the right sidle is divided.

The stomach was found to contain a mass of mammal fur and a piece of tree bark measuring $31 \times 26 \mathrm{~mm}$. obvionsly swallowed with the food.

DendRASPIS ANGUSTICEPS Smith.

Blgr. Cat. Snakes, iii. 1896 , p. 437.

Six specimens from Norogoro, Chanzuru, and Kilosa, and a 7 -foot specimen killed in the passage of a house at Mombasa.

The largest inale was 94 inches $(1880+502)$ and largest female was $97 \frac{1}{2}$ inches $(2332+139)$, Morogoro. Both Kilosa snakes were bright leaf-green and under 6 feet.

'T'wo newly-hatched young with the umbilical cord still unhealed were found on March 5th and 31st respectively, both at the same spot.

The one Kilosa specimen which was brought to me alive fed with avidity on dearl rats ; in fact, I think being nervous of large rats, mambas prefer them dead. As with my Morogoro examples, it would not commence to feer if anyone was about, possibly realising that it was at a disadvantage; however, by returning quietly $I$ succeerled in watching it feeding.

\section{I P E R I D A.}

Causus rhombeatus Licht.

Blgı. Cat. Snakes, iii. 1896 , p. 467.

Three examples of the Rhombic Night Adder were taken in Nairobi and the Ngong Forest.

During one week one of these adders swallowed a largish frog, three small toarls, and nine very small toads. On being chloroformed a week later and its stomach examined, all were found to have been completely digested except the feet of the frog. Another snake was seen by me to take seven small toads one after the other, each about the size of a thimble.

Causus resimus Peters.

Blgr. Cat. Snakes, iii. 1896 , p. 468.

'I'wo were taken at Liıguo and Sagayo.

'The Luguo specimen, though on redilish soil, was a beautiful grass-green; the Sagayo specimen, on the same kind of ground, was the usual greyish olive. Both with the normal markings. The former had 7 labials on the right lip and normal 6 on left; the latter 26 pairs of subcaudals. 
Causus defilippii Jan.

Blgr. Cat. Snakes, iii. 1896, p. 469.

A single specimen from Bagilo, Uluguru Mtns.

The largest of 15 specimens collected at Morogoro measured $16 \frac{3}{4}$ inches $(293+32)$; this series shows that the number of ventrals may range from 110 to 129 .

\section{Causus lichitensteini Jan.}

Blgr. Cat. Snakes, iii. 1896, p. 470.

This specimen was one of nine collected on the Yala River by Mr. H. J. Allen Turner and is now in the Nairobi Museum. Typical specimens are olive-green in life and plumbeous or leadcolour when preserved; the specimen under consideration agrees in every way with the published description of $C$.lichtensteini, except in the unusual markings and number of ventrals; but typical specimens from the same locality have also the same number.

Head and body $200 \mathrm{~mm}$.; tail $15 \mathrm{~mm}$.; costals 15 ; rentrals 158 ; caudals 17 ; labials 6 .

General colour grey (brilliant leaf-green in life like Chlorophis, but with a velvety tone-Turner). Head black. White line commencing at the first scale belind the last labial following the outline of the head passing along the edge of thesupracculars just above the eyes, and finishing on the corresponding scale on the other side. Lower portion of all the upper labials and whole of the 3rd china-white. An inverted $\mathrm{V}$ on nape, apex just reaching to posterior border of parietals. Throat pure white with a black $U$ corresponding to outline of throat and reaching to oral margin on the second labial only. Third and fourth gular scales (or ventrals) black, 5th and 6 th white, 7 th, 8 th, and 9 th black, 10 th and 11 th white, remaining ventrals grey with faint white transverse bars on every 13th or 14th scale. Black V-shaped markings along: whole of dorsal surface at intervals of seven to nine scales; nine very distinct white lateral marks corresponding to bars on the belly, the 10th just above vent forms a complete white ring three scales wide, white spot near tip of tail, white freckles on anterior part of black.

A nother specimen Mr. Turner tells me was quite black in life, similar to its preserved colour ; a brown stripe from the posterior border of the eye passes along the whole onter row of body scales ; the only other marking is a transverse brown band four scales wide across the back above the vent. Its formula is as follows :$267 \mathrm{~mm}$.; $26 \mathrm{~mm}$.; 15. 144 . 20.6 .

Biris arietans (Merr.).

Blgr. Cat. Snalses, iii. ]896, p. 493.

Twenty-one Puff Adders from Nairobi, Morogoro, Kilosa, Kipera, Mpanira-kwa-Sagoi, Mpwapwa, Usshora, and Lumbo. 
Most were taken lying on paths, but some in clearing or burning grass.

The largest males were $43 \frac{1}{2}$ and $40 \frac{3}{4}$ inches from Kilosa, the largest females $41 \frac{1}{2}$ and 39 inches from Morogoro, but none of these exceeded Catalogue dimensions. It is interesting to note that the skin of the largest when dried measured $52 \mathrm{in.}$

'The coloration is extremely variable in East African Puff Adders, which may be lemon-yellow, chocolate-brown, or brick-red, or intermediate between these three main types. A young reddish Puff Adder cast its skin on Nov. 7 th and appeared in a creamand-brown skin; exactly three months later, i.e. Feb. 9th, he sloughed again. On 17. viii. 21, I made a comparison of two young local snakes. A nut-brown one had a black spot on the lateral portions of each 5 th ventral scale approximately. The reddish viper, on the other hand, had the whole of the undersurface chequered with black like a Tessellated Snake.

The smaller of the two males whose measurements are given above was most unusually coloured : the black $V$-shaped markings had a lighter outer elge of old gold; posteriorly there were rectangular patches of the same colour. Another snake from Kipera which was driven out by fire from a woodland of maiombo bush, and which harmonised most wonderfully with the reddish soil and fallen brown and yellow leaves, had the V-shaped markings vermilion, black, and cream, the rest of the back being brown.

Some small boys informed me that two Puff' Adders, which are. known to the S'wahili as "Moma" or "Pilipili," were mating in the scrub not far from where $I$ was. There was only the male to be seen when I arrived, a very fine one, and it lay with hemipenes extruded perfectly motionless, nor did it move when I quietly placed a forked stick on its neck, not till I picked it. up did it commence to struggle. Pairing was taking place on Aug. 20th. A female very heavy in young was killed on 13.i. 21.

The Mpanira Adder had swallowed a largish bird whose quills were undigested. A younger specimen had an orthopteran in its stomach in addition to a young toad. Toads (Bufo regularis), but more often rats (R.c. microclon), are their principal food; so many persons have kept and recorded the feeding habits of this species that there is no object in my doing so here.

Three notes on the effects of their bite may not be amiss. A fine conditioned male Bushbuck was picked up at Kilosa on 26. iii. 21. There was a single puncture on one haunch, and from the fluid condition of the blood and general hemorrhage I should certainly say that the buck had laid upon (?) and been bitten by a. Puff Adder that morning.

When in the bathroom, my wife saw a rat entering by a hole which drains away the bath-water. When just clear of the hole, it struggled violently as if to free itself, and she thought she saw a snake's head and called to me that there was a snake there. The 
rat, meanwhile, ran up to the window-sill and entered a blind hole ; by the time I reached the room, the rat had jumped to the washstand and was lying dead with blood flowing from its left hind foot. As Puff Adders are very common here and Cobras rare, I am fairly certain it was the former. This occurred about 3 p.m., and 1 laid the rat by the hole, when, sure enough, it disappeared at dusk, as I supposed it would.

Just before dark one evening I was passing the cases containing. snakes when I saw that a 2 -foot Puff Adder had forced its head through a broken corner of the glass door. It could not get out further as it was too fat, nor could it withdraw itself owing to the triangular shape of the head. Taking hold of its neck with forefinger and thumb, I eased the belly scales past the glass with the left hand, then, shifting my grip to the head, was pressing on the quadrate bones and was on the point of letting go when the snake twisted round and drove its left fang down my thumb, scoring it so that it at once began to bleed. I imagine no venom was liberated, as I. suffered no serious consequences, though all precautions were immediately taken, my native helper lancing and ligaturing my thumb, which was immersed in a solution of permanganate so strong that it took all the skin off. I might ard that I put a rat into this Puff Adder's cage the following morning; the snake bit it, and the rat died very promptly and was duly swallowed. Whilst we were in camp at Lumbo a native died in hospital from a Puff Adder's bite.

A very large percentage of Puff Adders are infected with nematorle worms, which I believe at times are the cause of death, thus: Kilosa, 28. vii. 21-Young male adder found dead about fifteen feet from the kitchen door. Its stomach and intestines were very full of rat's fur; in the esophagus were a large number of immature ascarids which Dr. Baylis states are probably Polydelphis quadriconis (Wedl.).

Kilosa, 19. vii. 21-One of my Puff Adders not having ferl forfour months and being obviously unwell, I killed it. Beneath the skin it had four nodules or flattish lumps of flesh-like substance about $\frac{1}{2}$ inch long, $\frac{3}{8}$ inch wide, and $\frac{1}{8}$ or $\frac{1}{4}$ inch thick ; these uniterl the skin with the spine so that the reptile could not be skinned. Another snake lilled the same day had a large number of minute nematodes in the esophagus which Dr. Baylis states are Diaph.cnocephahus sp., and adds that the species is being described from other material by Daubeney under the name of $D$. obliquus.

In another the viscera was teeming with $P$. quadricornis, and there was also a sapeworm in the stomach.

Bitis gabonica Dum. \& Bibr.

Blgr. Cat. Snakes, iii. 1896 , p. 499.

My native collector shot a very fine specimen in the Usambara Mtns. and preserved the skin. I examined a second specimen from Kilwa, which is on the East Coast south of Dar es Salaan. 
Atractasris mostrata Giinth.

Blgr. Cat. Snakes, iii. 1896, p. 514.

Six specimens of the Snouted Burrowing Viper were collected at Lumbo from August to October 1918, and a female at Kilosa in April 1923.

All but one were females, and the largest of these measured $24 \frac{1}{2}$ inches $(614+8)$; a male had 21 , not 23 , scales round mid-body.

'These snakes are surprisingly quick, and when going to pick one up in a tent (it having been discovered by the moving of a box) it struck at my thumb. As I saw the snake lunge I was. also quick in withdrawing and just felt a prick on the top of my thumb, which at the time happened to be protected with somewhat horny skin; no venom was visible. 


\section{$2 \mathrm{BHL}$ Biodiversity Heritage Library}

Loveridge, Arthur. 1923. "43. Notes on East African Snakes, collected 1918-1923." Proceedings of the Zoological Society of London 1923, 871-897. https://doi.org/10.1111/j.1096-3642.1923.tb02212.x.

View This Item Online: $\underline{\text { https://www.biodiversitylibrary.org/item/97650 }}$

DOI: https://doi.org/10.1111/j.1096-3642.1923.tb02212.x

Permalink: https://www.biodiversitylibrary.org/partpdf/72014

\section{Holding Institution}

Smithsonian Libraries

\section{Sponsored by}

Biodiversity Heritage Library

\section{Copyright \& Reuse}

Copyright Status: Public domain. The BHL considers that this work is no longer under copyright protection.

This document was created from content at the Biodiversity Heritage Library, the world's largest open access digital library for biodiversity literature and archives. Visit BHL at https://www.biodiversitylibrary.org. 